\title{
PENGARUH AKTIVITAS FISIK TERSTRUKTUR TERHADAP PENINGKATAN PERSENTASE MASSA OTOT PADA ANGGOTA SANGGAR SENAM
}

\author{
Farah Zahida ${ }^{1}$, Fatimah Eliana Taufik ${ }^{2}$, Diniwati Muchtar ${ }^{3}$ \\ ${ }^{1}$ Fakultas Kedokteran Universitas YARSI Jakarta Pusat \\ ${ }^{2}$ Bagian Penyakit Dalam, Fakultas Kedokteran Universitas YARSI Jakarta Pusat \\ ${ }^{3}$ Bagian Fisiologi, Fakultas Kedokteran Universitas YARSI Jakarta Pusat
}

\begin{abstract}
ABSTRAK
Kesehatan sangat diperlukan dalam kehidupan. Banyak cara untuk memperoleh hidup sehat salah satunya dengan melakukan aktivitas fisik terstruktur. Aktivitas fisik memiliki dampak positif untuk mencegah penurunan massa otot. Massa otot merupakan jaringan tubuh yang berperan penting dalam kekuatan, kinerja serta regulasi metabolisme. Penelitian ini bertujuan untuk mengetahui pengaruh aktivitas fisik terstruktur terhadap peningkatan persentase massa otot. Penelitian ini dilakukan dengan rancangan penelitian one group pretest postest design. Populasi dan sampel adalah anggota sanggar senam R di Cempaka Putih dan K di Johar Baru sebanyak 36 orang. Sampel dipilih dengan menggunakan purposive sampling. Pengambilan data dilakukan dengan cara menimbang badan responden menggunakan timbangan Bioelectric Impedance Analysis (BIA) pada awal dan akhir penelitian. Analisis data dilakukan dengan uji statistik t-test menggunakan metode Wilcoxon. Terdapat peningkatan massa otot pada 14 orang (56\%) dari 25 responden dengan hasil uji Wilcoxon didapatkan nilai $\mathrm{P}=0.253$. Tidak terdapat pengaruh aktivitas fisik terstruktur dengan persentase massa otot pada anggota sanggar senam
\end{abstract}

Kata Kunci: Aktivitas fisik terstruktur, Massa otot, Anggota sanggar senam

\begin{abstract}
Health is very important in life. They are many ways for life healthy such as by doing structured physical activity. Physical activity has positive effect to prevent the decrement of muscle mass. Muscle mass is important for energy, performance and metabolism regulation. Therefore, the purpose of this study is tofind out the effect of the structured physical activity with the increment of muscle mass percentage on member of gymnastics studio This study is used the one group pretest postest design. The population and the sample are the member of $R$ and $K$ gymnastic studio in Cempaka Putih and Johar Baru with 36 people. The samples are chosen by purposive sampling. The data are collected by measuring the respondent's body with Bioelectrical Impedance Analysis on the begining and the ending of this study. The data is analyzed with t-test used Wilcoxon method. Fourteen respondents (56\%) from twenty-five have their muscle mass percentage increased with the p value 0,253. There are no significant effect within the strucured physical activity and the increase of muscle mass percentage on member of gymnastics studio.
\end{abstract}

Keywords: Physical activity, Muscle mass, member of gymnastic studio 


\section{Pendahuluan}

Kesehatan sangat diperlukan
dalam kehidupan di masyarakat
karena dengan hidup sehat maka
seseorang dapat menjalani
kehidupan. Banyak cara bisa
dilakukan untuk memperoleh hidup
sehat salah satunya dengan
melakukan aktivitas fisik terstruktur. Latihan fisik yang terarah dapat memperbaiki bentuk, fungsi, ketahanan dan kekuatan otot (Kalangi, 2014; Soethama et al, 2015). Latihan fisik adalah semua bentuk aktivitas fisik yang dilakukan secara terstruktur dan terencana, dengan tujuan untuk meningkatkan kesegaran jasmani (Kementrian Kesehatan RI, 2012). Dua jenis perubahan dapat ditimbulkan pada serat otot yaitu latihan daya tahan aerobik yang teratur, misalnya jalan, lari kecil, bersepeda dan berenang. Latihan resistensi anaerob berintensitas tinggi dan berdurasi singkat, misalnya angkat beban (Sherwood, 2014). Program latihan yang dianjurkan untuk meningkatkan kesegaran jasmani adalah CRIPE (Continous, Rhytmical, Interval,
Progressive and Indurance), latihan dilakukan terus menerus, berirama, terselang-seling (cepat atau lambat), peningkatan secara bertahap dan meningkatkan kesegaran serta ketahanan kardiovaskular (Sinaga, 2016).

Aktivitas fisik merupakan setiap pergerakan tubuh akibat kontraksi otot rangka yang membutuhkan kalori lebih besar daripada pengeluaran energi saat istirahat (Pascatello et al, 2014). Aktivitas fisik dikategorikan cukup apabila seseorang melakukan aktivitas fisik atau olahraga selama 30 menit setiap hari atau minimal 3-5 hari dalam seminggu. Dampak positif dari aktivitas fisik untuk mencegah penurunan massa otot (Nishiguchi et al, 2014).

Riset Kesehatan Dasar (Riskesdas) tahun 2007 menyatakan bahwa 48.2 persen penduduk Indonesia yang berusia lebih dari 10 tahun kurang melakukan aktivitas fisik dan kelompok perempuan yang kurang melakukan aktivitas fisik (54.5 persen) lebih tinggi dari kelompok laki-laki (41,4 persen). Kelompok dewasa tua yang 
melakukan aktivitas fisik terbukti memiliki fisik yang baik dan hidup lebih aktif daripada kelompok dewasa tua yang tidak melakukan aktivitas fisik.

Massa otot merupakan jaringan tubuh yang berperan penting dalam kekuatan, kinerja seperti olahraga dan aktivitas sehari-hari serta regulasi metabolisme. Massa otot skeletal meningkat ketika dalam masa pertumbuhan dan setelah pertumbuhan terhenti biasanya tidak ada lagi kenaikan bersih massa otot. Bertambahnya kekuatan otot yang diperoleh melalui latihan tidak dapat diperoleh begitu saja. Memerlukan waktu latihan rutin selama dua bulan barulah akan didapat peningkatan yang bermakna. Peningkatan kekuatan ini harus dipelihara terus sebab peningkatan yang telah dicapai dalam waktu dua bulan itu akan hilang sama sekali jika tidak berlatih selama lima bulan berikutnya. Massa otot menurun sekitar 1-2\% per tahun setelah usia 50 tahun. Penelitian longitudinal juga menunjukkan pada sekitar usia 35 tahun telah terjadi penurunan kekuatan, kepadatan dan massa otot (Kalangi, 2014; Devries et al, 2015). Kesehatan pada usia paruh baya dapat ditingkatkan untuk mencegah penurunan massa otot.

Data Riset Kesehatan Dasar 2013, menunjukkan bahwa Jakarta merupakan provinsi tertinggi dengan penduduk yang kurang melakukan aktivitas fisik, oleh karena itu peneliti memilih Jakarta Pusat, khususnya daerah Cempaka Putih dan Johar Baru sebagai lokasi penelitian. Akses yang dekat dan banyak sanggar senam menjadi pemilihan lokasi penelitian. Berdasarkan hasil uraian diatas maka peneliti tertarik untuk mengetahui apakah aktivitas fisik berpengaruh terhadap perubahan massa otot.

\section{Metode Penelitian}

$$
\begin{aligned}
& \text { Penelitian ini berupa } \\
& \text { penelitian eksperimental dengan } \\
& \text { rancangan penelitian berupa one } \\
& \text { group pretest posttest design. } \\
& \text { Populasi dan sampel adalah anggota } \\
& \text { sanggar senam R di Cempaka Putih } \\
& \text { dan K di Johar Baru sebanyak } 36 \\
& \text { orang. Sampel dipilih dengan } \\
& \text { menggunakan purposive sampling. } \\
& \text { Pengambilan data dilakukan dengan } \\
& \text { cara menimbang badan responden } \\
& \text { menggunakan timbangan Bioelectric }
\end{aligned}
$$


Impedance Analysis (BIA) pada awal dan akhir penelitian. Analisis data dilakukan dengan uji statistik t-test menggunakan metode Wilcoxon. Sampel dipilih berdasarkan kriteria inklusi dan ekslusi. Kriteria inklusi penelitian berupa anggota sanggar senam yang mengikuti program aktivitas fisik terstruktur selama periode 3 bulan di sanggar senam Cempaka Putih dan Johar Baru, rentang usia 18-60 tahun. Kriteria eksklusi penelitian berupa tidak mengikuti program selama periode 3 bulan dan hamil.

\section{Pembahasan}

Berdasarkan hasil pengambilan sampel yang dilakukan pada responden yang memenuhi kriteria inklusi yaitu sebanyak 25 orang dengan rata-rata massa otot $24,6 \%$, terdapat 14 orang yang mengalami peningkatan massa otot, 2 orang memiliki hasil yang tetap dan 8 orang mengalami penurunan massa otot. Pada hasil yang didapatkan jumlah orang yang mengalami peningkatan massa otot lebih banyak dibandingkan yang tidak mengalami peningkatan. Kemudian setelah dilakukan uji analisis Wilcoxon didapatkan $\mathrm{P}=$ 0.253 menandakan tidak ada hubungan antara aktivitas fisik terstruktur terhadap peningkatan massa otot. Hal ini disebabkan oleh faktor-faktor yang dapat mempengaruhi peningkatan massa otot, yaitu aktivitas fisik di luar program penelitian dan asupan makanan. Aktivitas fisik yang mempengaruhi peningkatan massa otot menurut Wiarto (2013) adalah aktivitas olahraga yang bersifat kekuatan, contohnya olahraga angkat beban. Olahraga tersebut lebih mudah untuk meningkatkan massa otot. Hal ini sejalan dengan penelitian Hulmi et al. (2009) dimana subjek yang melakukan latihan angkat beban dua kali seminggu selama 21 minggu mengalami peningkatan massa otot (Putra dan Amalia, 2014).

Peneliti tidak melakukan kontrol terhadap asupan makanan responden dan aktivitas fisik lain yang dilakukan responden di luar program penelitian. Berdasarkan wawancara didapatkan responden yang mengalami kenaikan massa otot 
sering mengosumsi makanan berprotein, seperti susu dan ikan.

\section{Hasil}

Penelitian ini dilakukan pada dua kelompok senam di sanggar senam $\mathrm{R}$ di Cempaka Putih dan K di GOR Johar Baru. Responden melakukan aktivitas fisik terstruktur minimal tiga kali seminggu berupa senam aerobik minimal 150 menit per minggu selama 12 minggu. Pada awal penelitian total responden berjumlah 36 orang. Selama penelitian berlangsung, sebanyak 4 orang mengundurkan diri, 7 orang tidak sesuai dengan kriteria inklusi penelitian sehingga tersisa 25 orang yang kemudian dilakukan analisis dengan menggunakan metode SPSS versi 25 dan dilakukan follow up selama 12 minggu.

Tabel 7. Rata-rata Hasil Persentase

\section{Massa Otot}

\begin{tabular}{ccc}
\hline $\begin{array}{c}\text { Sebelum Senam } \\
\text { Aerobik }\end{array}$ & $\begin{array}{c}\text { Setelah Senam } \\
\text { Aerobik }\end{array}$ & P-Value \\
\hline 24,41 & 24,64 & 0,253
\end{tabular}

Tabel 8. Hasil Persentase Massa Otot Awal dan Akhir Penelitian

\begin{tabular}{|c|c|c|c|c|}
\hline \multirow[t]{2}{*}{ No } & \multirow{2}{*}{$\begin{array}{c}\text { Usia } \\
\text { (Tahun) }\end{array}$} & \multirow{2}{*}{$\begin{array}{c}\mathrm{IMT} \\
\left(\mathrm{kg} / \mathrm{m}^{2}\right)\end{array}$} & \multicolumn{2}{|c|}{ Massa Otot (\%) } \\
\hline & & & Sebelum & Sesudah \\
\hline 1 & 43 & 25,4 & 23,1 & 23,4 \\
\hline 2 & 38 & 25,7 & 24,3 & 24,9 \\
\hline 3 & 38 & 20,7 & 26,3 & 26,8 \\
\hline 4 & 38 & 23,5 & 23,2 & 23,9 \\
\hline 5 & 21 & 23,6 & 26,8 & 27 \\
\hline 6 & 22 & 25,1 & 24,6 & 24,4 \\
\hline 7 & 21 & 42 & 21 & 24 \\
\hline 8 & 21 & 23 & 27,4 & 27,2 \\
\hline 9 & 21 & 28,3 & 26,3 & 27,6 \\
\hline 10 & 39 & 22,6 & 26,9 & 26 \\
\hline 11 & 41 & 25,3 & 25 & 24,2 \\
\hline 12 & 31 & 24 & 26 & 26,1 \\
\hline 13 & 38 & 27,2 & 23,5 & 23,4 \\
\hline 14 & 54 & 23,3 & 22,4 & 22,4 \\
\hline 15 & 42 & 28 & 22,7 & 23 \\
\hline 16 & 45 & 25,6 & 24,6 & 24,1 \\
\hline 17 & 40 & 21,7 & 24,3 & 24,7 \\
\hline 18 & 38 & 26,7 & 22,5 & 22,7 \\
\hline 19 & 35 & 23,8 & 26,1 & 25,5 \\
\hline 20 & 41 & 26,5 & 25,2 & 25,8 \\
\hline 21 & 44 & 42,3 & 21,1 & 21 \\
\hline 22 & 45 & 23,3 & 23,3 & 23,5 \\
\hline 23 & 34 & 18,7 & 27,9 & 27 \\
\hline 24 & 55 & 22,2 & 23,1 & 23,1 \\
\hline 25 & 48 & 30,6 & 22,8 & 24,3 \\
\hline
\end{tabular}




\section{Kesimpulan}

Berdasarkan penelitian yang

dilakukan di sanggar senam

Cempaka putih dan Johar Baru,

Jakarta Pusat 2017-2018 didapatkan

kesimpulan aktivitas fisik terstruktur

dapat meningkatkan persentase

massa otot pada beberapa anggota

sanggar senam di Cempaka Putih dan

Johar Baru, namun secara statistik tidak bermakna

\section{Saran}

Bagi Peneliti Selanjutnya agar lebih menjaga kepatuhan responden, lebih tegas dalam memberikan aturan yang harus diikuti kepada responden, memperhatikan pola makan responden. Bagi anggota sanggar senam agar lebih memperhatikan pola hidup, seperti rutin melakukan aktivitas fisik terstruktur, menjaga pola makan, menghindari merokok karena hal-hal tersebut saling berkaitan satu sama lain dalam menjaga kesehatan

\section{Daftar Pustaka}

1. Advisory Committee Report. 2008. Physical Activity

Guidelines Advisory Committee Report. Department of Health and Human Services:43-84

2. Bouchard C, Shephard RJ, Stephens T.1993. Physical Activity, Fitness, and Health Consensus Statement. Human Kinetics Publishers : Canada

3. Devries MC, Philips SM. 2015. Supplemental Protein in Support of Muscle Mass and Health:Advantage Whey. Journal of Food Science 80:A8-A15

4. Kalangi SJR. 2014. Perubahan Otot Rangka pada Olahraga. Jurnal Biomedik $(J B M)$ $6(3): 172-$

5. Kementerian Kesehatan RI. 2014. Pedoman gizi seimbang. Diperoleh dari http://gizi.depkes. go.id/download/Pedoman\%20Gizi /PGS\%20k.pdf. $\quad$ Diakses pada tanggal 13 Desember 2016 
Nishiguchi Shu, Yamada Minoru,

Kajiwara Yuu, Sonoda

Takuya, Yoshimura Kazuya, Kayam

Hiroki, Tanigawa Takanori, Yukutake Taiki, Aoyama Tomoki. 2014. Effect

of physical activity at midlife on skeletal muscle mass in old age in communitydwelling older women: A crosssectionalstudy. Journal of Clinical Gerontology \& Geriatrics 5:18-22 Sinaga RN. 2016. Diabetes Melitus dan Olahraga. Jurnal Ilmu

Keolahragaan 15(2) : 21-29

Sherwood, Lauralee.2014. Fisiologi

Manusia dari Sel ke Sistem Edisi 8. EGC :Jakarta

Soethama GRR, Silakarma Dedi, Wiryanthini Ida, Ayu Dewi. 2015.

Pengaruh Latihan Beban terhadap Peningkatan Pectorals Mayor dan Biceps pada Remaja dan Dewasa. Majalah Ilmiah Fisioterapi

Indonesia 2(1):52-57
Wiarto G. 2013. Fisiologi dan Olahraga. Graha ilmu : Yogyakarta

World Health Organization. 2010.

Global Recommendations on

PhysicalActivity for Health.

Geneva, Switzerland World

Health Organization Press

World Health Organization 2017, Physical Activity, Diperoleh dari http://www.who.int/topics/ph ysical_activity/en/, diakses pada 20 Februari 2017 